\title{
РОЗРОБКА СТЕНДА ДЛЯ ДОСЛІДЖЕННЯ РЕЖИМІВ УПРАВЛІННЯ ТЕХНОЛОГІЧНИМ ПРОЦЕСОМ ОБРОБКИ БІОПОЛІМЕРІВ РОСЛИННОГО ПОХОДЖЕННЯ ПОВІТРЯМ, ЗБАГАЧЕНИМ ОЗОНОМ
}

\author{
Бабков А.В. ${ }^{1}$, Гриняк А.М. ${ }^{1}$ \\ ${ }^{1}$ Одеська Національна академія харчових технологій, Одеса.
}

Copyright (C) 2014 by author and the journal "Automation technological and business - processes". This work is licensed under the Creative Commons Attribution International License (CC BY). http://creativecommons.org/licenses/by/4.0/

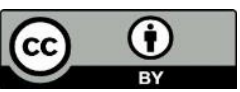

\section{Анотація}

Розглянуті різні способи синтезу озону в електричних розрядах. Спроектовано та змонтовано лабораторний стенд для проведення досліджень впливу збагаченого озоном повітря на біополімери рослинного походження при їх обробці у потоці та насипі.

\section{Abstract}

Considered different ways of synthesis ozone in electrical discharges. Designed and assembled laboratory stand for studies of the impact of ozone-air mixture on the biopolymers of plant origin when they are processed in the flow and mound.

Ключові слова

Озон, синтез, біополімери рослинного походження, дослідне обладнання.

\section{Вступ}

При проведенні наукових досліджень, спрямованих на вивчення впливу нових засобів, режимів і підходів до обробки, переробки і інших процесів, що викликають зацікавленість дослідників в галузі харчових технологій, зазвичай постає питання про необхідність перевірки або моделювання теоретичних викладень. Для розв'язання цих та інших задач, які супроводжують дослідження сучасних науковців, використовується багато різноманітного лабораторного обладнання і дослідних стендів, що допомагають дослідникам у лабораторних умовах вивчити цікаві для них аспекти тих чи інших процесів.

Саме тому для вивчення впливу повітря, збагаченого озоном (ПЗО), на біополімери рослинного походження (БРП) і розробки нових інноваційних технологій, що засновані на використанні ПЗО у зернових i зернопереробних галузях АПК, постало питання про необхідності створення дослідного стенду, на базі якого можливо провести натурні дослідження обробки ПЗО БРП. В основу дослідного стенду необхідно було закласти зменшену модель імовірних напрямів використання ПЗО: при потоковій респіраційній обробці або потоковому охолодженню і обробці у насипу БРП (таких як зерно), відповідно до схеми деяких технологічних ділянок елеваторів та зернопереробних підприємств, на яких використовують обробку зерна атмосферним повітрям [1]. Будь-яка подібна робота по створенню необхідного для досліджень обладнання, зазвичай починається із літературного огляду і аналізу імовірних шляхів вирішення низки технічних питань, зокрема, питання про імовірні механізми утворення озону і вибір способу синтезу озону, який задовольнить основні потреби при використанні стену. 


\section{$\underline{5}$ ТЕОРІЯ I ПРАКТИКА АВТОМАТИЗАЦЇ̈ БІЗНЕС-ПРОЦЕСІВ}

Літературний огляд

Важливою складовою частиною аналізу способів синтезу озону є розуміння фізичних та хімічних його властивостей, а також принципів роботи обладнання, яке використовують для цієї мети. Озон $\left(\mathrm{O}_{3}\right)-$ друга відносно стійка (метастабільна) проста молекулярна сполука, яку разом з формою $\mathrm{O}_{2}$ утворює кисень. Всього відомі сім простих сполук кисню, включаючи комплекси $\mathrm{O}_{4}$ i $\mathrm{O}_{6}$.

Значна реакційна здатність озону пов'язана із структурою його молекули. Молекула озону складається 3 трьох атомів кисню. У валентній оболонці кожного з атомів кисню знаходяться два неспарені електрони, кожен 3 яких займає одну $2 p$-орбиталь. Це означає, що при формуванні молекули озону три атоми кисню з'єднуються за допомогою перетину площин орбіталей бічних і центрального атома кисню $s p^{2}, 2 s$ і $2 p$, у валентній зоні. Реалізується будова, в якій три нові $s p^{2}$ гібридні орбіталі утворюють трикутник з кисневим ядром в центрі, тобто під кутом $116^{\circ} 49^{\prime}$, як показано на рис 1.

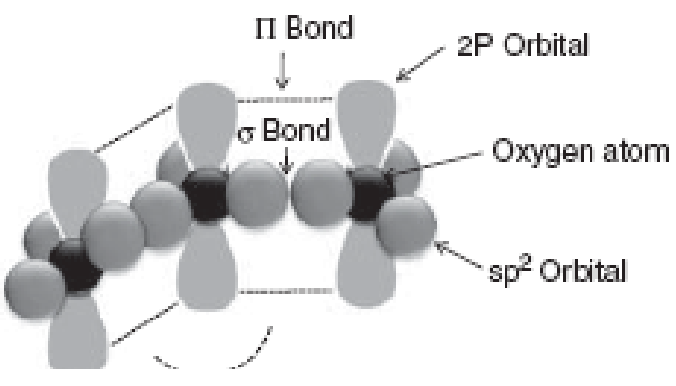

Рис. 1. Молекулярна структура озону

Конфігурація молекули озону виникає внаслідок об'єднання $s p^{2}$ i $2 p^{2}$ орбіталей, при цьому дві 9-молекулярні орбіталі переміщаються по усій молекулі озону. Внаслідок цього молекула озону, є гібридною формою чотирьох можливих структур. Висока реакційна здатність озону може бути обумовлена електронною конфігурацією молекули, викликаною відсутністю електронів в одному 3 терміналів атомів кисню в деяких резонансних структурах, що підтверджує електрофільний характер озону, тоді як надмірний негативний заряд, присутній в інших атомах

кисню, надає йому нуклеофільний характер [2].

По окислювальній здатності озон (окислювальний потенціал 2,07 В) займає третє місце серед відомих окисників, поступається фтору (окислювальний потенціал 2,41 В) i фториду кисню, тоді як хлор (окислювальний потенціал $1,73 \mathrm{~B})$ - займає восьме, а звичайний кисень $\left(\mathrm{O}_{2}\right)$ тільки тринадцяте місце. Своєю високою активністю озон зобов'язаний, в основному, атомарному кисню, який він легко віддає при дисоціації молекули в хімічній реакції [3].

Найбільш повнішою, високопрофесійною і такою, що відповідає напрямку літературного огляду, є робота Є. Сілкіна [4], яку у подальшому було узято за основу і доповнено згідно із дослідженнями і викладками авторів статті.

Більш економічно вигідним способом отримання озону в промислових масштабах нині вважається його синтез в електричних розрядах з кисню або кисневмісних сумішей газів. Слід зазначити, що електросинтез озону, як правило, досить енергоємний процес. Одиничні продуктивності діючих озонних заводів досягають 1000 кг $\left(\mathrm{O}_{3}\right) /$ год. при встановленій потужності устаткування більше 50 МВт. При цьому синтезується озон високих (до 150 г $\left(\mathrm{O}_{3}\right) / \mathrm{M}^{3}$ ) і надвисоких (більше $200 \Gamma_{3} \mathrm{O}_{3} / \mathrm{M}^{3}$ ) масових концентрацій. Підвищення концентрацій викликає істотне зростання витрат енергії на отримання озону.

Згідно з сучасними уявленнями, озон синтезується в середовищі, що містить кисень, якщо виникнуть умови, при яких утворюється атомарний кисень або молекулярний кисень дисоціює на атоми. Важливо тут те, що для отримання значних концентрацій і істотного виходу озону, потрібні порівняно низька температура і наявність великих (надрівноважних) концентрацій атомарного кисню. Це може мати місце, зокрема, при різних дисоціативних нетермічних діях на газове середовище, що містить кисень, або при термічних діях, якщо забезпечуються умови збереження (загартування) надрівноважних концентрацій атомарного кисню при низьких температурах. Тобто, при отриманні озону в газовому середовищі, основним є дисоціативний механізм його синтезу. Власне синтез озону в газовому середовищі включає три групи реакцій: дисоціація молекулярного кисню, утворення озону і його розпад. Кожна з вказаних груп реакцій може складатися 3 декількох, іноді багатьох реакцій, так що повний механізм синтезу включає значне число стадій, паралельних каналів і реакцій. Відомі більше 100 «основних» хімічних реакцій утворення і розкладання озону в газовому середовищі, що узгоджуються $з$ дисоціативним механізмом. Крім того, висуваються гіпотези про утворення озону в газовому середовищі і по інших механізмах, зокрема, через збуджені стани молекулярного кисню $\mathrm{O}_{2}$, розпад комплексів $\mathrm{O}_{6}$, а також по різних іонних механізмах. Такі механізми синтезу озону цілком вірогідні. Більше того, вони, безумовно, відіграють певну роль в деяких реальних процесах. Проте вклад вказаних реакцій в основний дисоціативний механізм синтезу озону (у практично реалізованих технологічних процесах), як вважається, 


\section{$\underline{5}$ ТЕОРІЯ І ПРАКТИКА АВТОМАТИЗАЦІЇ БІЗНЕС-ПРОЦЕСІВ}

незначний. Тут слід розуміти, що в остаточному виді механізм синтезу озону проаналізувати практично неможливо, і не лише внаслідок його складності, а, в першу чергу, через неможливість обліку усього різноманіття чинників, що впливають на процес. Кожного разу, внаслідок не повторюваності умов, доводиться мати справу фактично з новою формою електричного розряду, в результаті можливо застосувати лише деякі окремі узагальнення. Умовно група реакцій, що призводять до синтезу озону за дисоціативним механізмом (без урахування можливих енергетичних ланцюгів), наступна [3]:

$$
\begin{aligned}
& \mathrm{O}_{2}+\mathrm{q} \rightarrow \mathrm{O}+\mathrm{O}+\mathrm{q}, \\
& \mathrm{O}+\mathrm{O}_{2}+\mathrm{M} \rightarrow \mathrm{O}_{3}+\mathrm{M},
\end{aligned}
$$

де q — частка високої енергії, наприклад електрон, фотон, збуджений атом або молекула буферного газу, домішки і т. п., М- будь-яка частка, наприклад атом або молекула кисню, молекула озону, атом, або молекула домішки, діелектричний шар і т. п.

«Потрійне» зіткнення (2) потрібне, оскільки необхідно відвести надлишок енергії (реакція власне утворення озону екзотермічна, тобто йде з виділенням тепла). В цілому ж синтез озону - процес ендотермічний. Для його здійснення вимагаються витрати зовнішньої енергії, яка витрачається, у тому числі, і на дисоціацію кисню [3, 4].

При будь-яких способах синтезу озону відбувається також низка реакцій, в результаті яких озон розкладається. Групу реакцій розкладання озону можливо представити у вигляді механізму С. Бенсона [3]:

$$
\begin{aligned}
& \mathrm{O}_{3}+\mathrm{q} \rightarrow \mathrm{O}+\mathrm{O}_{2}+\mathrm{q}, \\
& \mathrm{O}_{3}+\mathrm{M} \rightarrow \mathrm{O}+\mathrm{O}_{2}+\mathrm{M}, \\
& \mathrm{O}_{3}+\mathrm{O} \rightarrow \mathrm{O}_{2}+\mathrm{O}_{2} .
\end{aligned}
$$

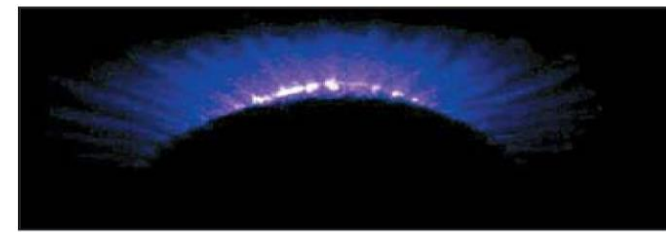

Рис. 2. Структура коронного разряду в газі

Утворення озону можливе в усіх відомих формах електричного розряду в середовищі, що містить кисень. При цьому дисоціація молекул кисню в розрядах в газовому середовищі в основному здійснюється за рахунок зіткнень молекул 3 прискореними в електричному полі електронами (дисоціація електронним ударом). Додатковими чинниками можуть бути ультрафіолетове випромінювання самого розряду і зіткнення молекул кисню зі збудженими атомами або молекулами, у тому числі з атомами або молекулами домішок. Найбільш економічні витрати енергії для електросинтезу озону це: кистьовий (з «вістря») і бар’єрний («тихий») розряди в потоці газу, що містить кисень. Деякі дослідники вважають їх по суті коронними. Проте це, безумовно, різні форми електричного розряду. Часто коронним називають саме кистьовий розряд (рис. 2).

У кистьових розрядах технологічно складно отримати озон високих концентрацій внаслідок малого відносного об'єму зони іонізації $\Lambda$, що реалізовується:

$$
\Lambda=V_{\mathrm{I}} / V_{\mathrm{P}}
$$

де $V_{\text {I }}$ - частина об'єму реактора, зайнятого плазмою розряду, $V_{\mathrm{P}}$ - загальний об'єм реактора. Тому генератори озону на кистьовому розряді обмежено застосовуються, в першу чергу, в схемах очищення $\mathrm{i}$ дезінфекції повітря і технологічних газів, де не потрібний озон високих концентрацій. Цей аспект $\epsilon$ характерним як для кистьових так і інших без бар'єрних способів синтезу озону та підтверджений власними дослідженнями [1].

У промислових генераторах озону реалізується, як правило, бар'єрний розряд в об'ємі або поверхневий (той,

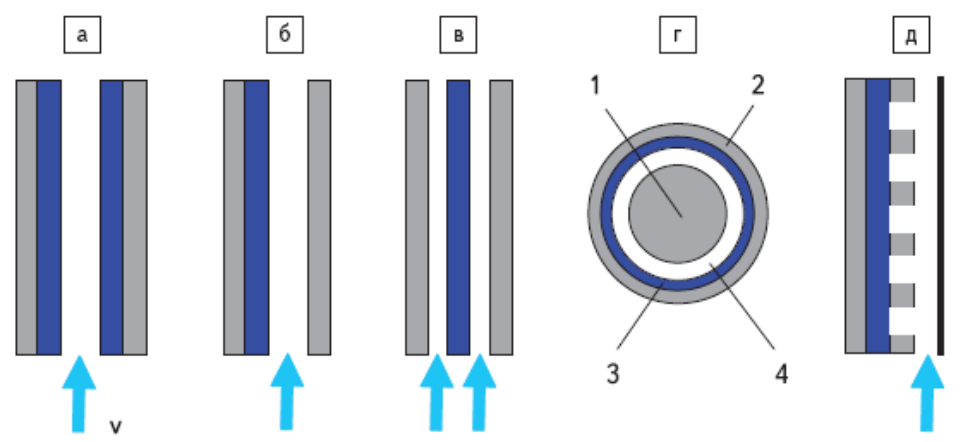
що ковзає), бар'єрний розряд. Бар'єрний розряд - це особлива форма електричного розряду, що виникає в середовищі між електродами реактора, розділеними діелектричним шаром (бар'єром) і розрядним проміжком, що заповнюється частками середовища, якщо до електродів прикладена різниця потенціалів достатньої (для виникнення розряду) величини. Струм розряду обмежується діелектричним шаром.

Рис. 3. Схеми конструкцій генераторів озону бар'єрного 
Діелектричний шар стабілізує струм розряду генератора озону і надає бар'єрному розряду в об'ємі реактора рівномірний характер. Як показали дослідження [5], діелектричний шар відіграє важливу роль в процесі електросинтезу озону, і його властивості визначають в цілому якість, надійність і продуктивність генератора. На рис. 3 приведені основні схеми конструкцій генераторів озону. Потік часток середовища (v) проходить через розрядний проміжок 4 між електродами 1 i 2 . Наявність діелектричного шару 3 обумовлює застосування для електроживлення генератора озону джерела змінного (чи імпульсного) струму. Електроди 1 i 2 можуть мати як пласку (рис. 3, а-в) так і циліндричну (рис. 3, г) форму. При цьому діелектричний шар 3 покриває один (рис. 3 , б) або обидва електроди 1 і 2 (рис. 3, а, г), або розділяє розрядний проміжок на дві частини при виконанні у вигляді самостійного елементу (рис. 3, в). У генераторі озону ковзаючого розряду (рис. 3 , д) суцільний електрод відокремлений від секціонованого електроду діелектричним шаром. Як такий розрядний проміжок в ньому явно відсутній. Озон утворюється в розряді на поверхні діелектричного шару в потоці часток середовища, що проходить над секціонованим електродом.

Винахід перших конструкцій генераторів озону пов'язаний з іменами Е. Сименса (Е. Simens, 1857 p.) i Н. Тесла (N. Tesla, 1896 р.). У 1897 р. Е. Сименс розробив конструкцію, і ідеї, закладені в ній, передбачили усі наступні, що були реалізовані при подальших спробах модернізації генераторів бар'єрного розряду в об'ємі для електросинтезу озону, аж до наших днів. Генератори озону з одним діелектричним шаром запропонував Е. Фролих (E. Frolich, 1891 р.). Циліндричні (трубчасті) генератори з одним діелектричним шаром, названі також генераторами Велсбаха (H. Welsbach), нині є найпоширинішою конструкцією потужних високопродуктивних генераторів для електросинтезу озону.

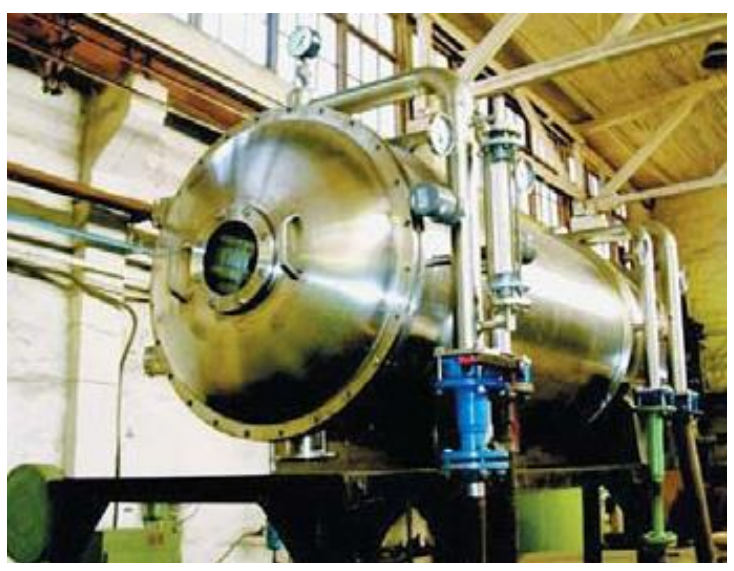

Рис. 4. Зовнішній вигляд генератора озону Велсбаха

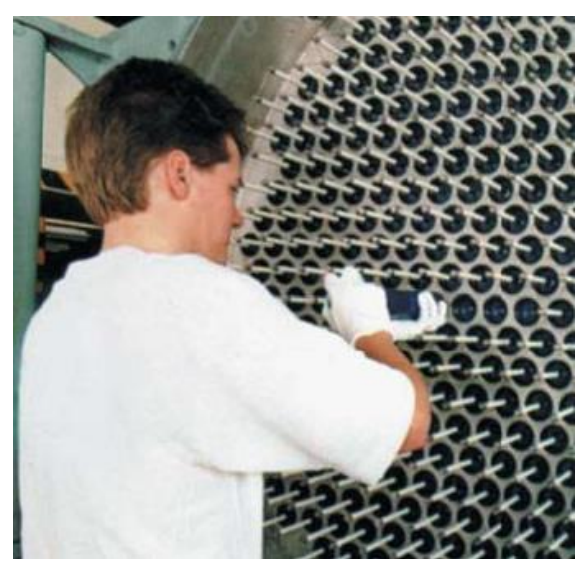

Рис. 5. Конструкція генератора озону Велсбаха

Генератори Велсбаха, як правило, виконуються у вигляді герметичних резервуарів циліндричної форми (рис. 4) які мають «сотову» структуру. Заземленими («низьковольтними») електродами є металеві трубки, які омиває вода, для охолодження, а «високовольтними» - скляні трубки меншого діаметру, на внутрішню поверхню яких нанесений шар графіту або алюмінію. Скляні трубки мають менший зовнішній діаметр i розміщуються усередині металевих трубок, при цьому утворюється рівномірний проміжок - розрядний проміжок. При проходженні через нього кисневмісного газу і подачі на електроди «високої» змінної напруги в розрядному проміжку виникає розряд і утворюється озон. Металеві і скляні трубки об'єднуються в резервуарі (корпусі) паралельно потоку газу в комплект заданої продуктивності (рис. 5). Число паралельних трубок в комплекті потужного високопродуктивного генератора озону може бути значним (до 1000 шт.). Саме таку конструкцію мають генератори відомих зарубіжних фірм (Ozonia, Trailigaz, Degremont, Osmonics, Fuji, «Курганхиммаш», «Озонит»). В принципі, конструкцію Велсбаха не можна визнати вдалою. Діелектричний шар в ній охолоджується тільки потоком газу. В той же час, як показали деякі дослідження, саме діелектричний шар необхідно охолоджувати найінтенсивніше. Широке застосування генераторів Велсбаха обумовлене, в першу чергу, технологічністю конструкції. В зв'язку з цим цікава розробка фірми Fuјi. Це також циліндричний генератор Велсбаха з одним діелектричним шаром (свинцеве скло). Проте цей шар в генераторі Fuji наноситься на внутрішню поверхню металевих трубок. Умови охолодження діелектричного шару при цьому покращуються, характеристики його стабілізуються. В результаті досягається істотне підвищення продуктивності, при певному погіршенні технологічності і ремонтопридатності конструкції. Конструкцію 


\section{$\underline{5}$ ТЕОРІЯ І ПРАКТИКА АВТОМАТИЗАЦІЇ БІЗНЕС-ПРОЦЕСІВ}

генератора озону з пласкими (пластинчастими) електродами запропонував А. Востмаєр (A. Vostmaer, 1916 p.). Для роботи генераторів озону бар'єрного розряду в об'ємі, відмінність у формі електродів (циліндричні вони або пласкі) не є принциповою.

При синтезі озону в промислових умовах застосовують генератори з розрядними проміжками 0,1-4,0 мм, діелектричними шарами завтовшки 0,2-3,0 мм (3 відносною діелектричною проникністю 5-50). В якості матеріалів для діелектричних шарів найчастіше використовуються різні типи скла і склоемалей, рідше кераміки, пористих пластиків і пластмас. Матеріалами для електродів є нержавіюча сталь, алюміній або титан і їх сплави. Напруга електроживлення генераторів озону складає 1-30 кВ (живлення здійснюється через погоджувальний або розв'язуючий трансформатор), а частота - 0,05-20 кГц. Тиск кисневмісного газу може бути 0,02-0,2 МПа, а максимальна швидкість потоку досягати 200 м/с. Це істотні умови, 3 яких виходить, що бар'єрний розряд здійснюється в потоці газу при відносно високих тисках і порівняно низьких швидкостях. Робочі частоти промислових генераторів озону знаходяться в діапазоні, в якому пробивна напруга газу практично не залежить від частоти.

\section{Постановка проблеми і шляхи ії вирішення}

Відштовхуючись від світового досвіду і технічних характеристик, що були сформовані у відповідності до технологічних ділянок на яких проводиться обробка БРП повітрям у потоці та насипу, дослідний стенд повинен складатися із: генератору озону, вентилятору або компресору, що нагнітає повітря у спеціальний вихідний патрубок оснащений кріпленням, яке повинно бути розташоване на вихідному патрубку для під'єднання до нього допоміжної конструкції, що дозволить імітувати зерновий самоплив. Крім того, конструкція генератору озону повинна бути оснащена регулюючим органом, який допоможе коректувати вихідну концентрацію озону, що синтезується, індикатором частоти розрядів, які виникають на електродах реактору генератора, а вентиляційна установка, що нагнічує повітря і синтезований у реакторі озонатору озон, повинна мати можливість збільшити інтенсивність потоку при потребі подолання аеродинамічного опору використаних у дослідах зразках БРП.

\section{Результати і їх обговорення}

Розглядаючи конструкції бар'єрних генераторів озону, можна відмітити, що вони є електричними приладами, конструктивно подібним до багатошарового конденсатора, що має два або більше послідовно сполучених діелектричних шари (бар'єри і розрядний проміжок) 3 різною діелектричною проникністю. Аналізуючи можливості, та технічні властивості існуючих промислових та побутових озонаторів, були зроблені висновки про те що, жоден з присутніх на ринку технічних засобів за тими або іншим критеріям не відповідає вимогам, і їх використання у дослідній роботі стає некоректним, або обмеженим. Тому для виконання лабораторних досліджень був розроблений і змонтований експериментальний дослідний стенд із вмонтованим генератором озону на основі бар'єрного розряду з використанням пласких електродів (див. рис. 3., в) та можливістю застосування різних діелектричних матеріалів у якості бар'єру (скло, кераміка і т. п.). За основу була узята одна 3 моделей побутового озонатору розробленого Дзержинським НДІ хімічного машинобудування [6]. Конструктивно, в розробленому приладі, була передбачена можливість зміни та регулювання розрядного проміжку та зміни напруги на електродах реактору. При розробці у якості основної вхідної сировини для синтезу озону, була закладена можливість використання атмосферного повітря, яке за допомогою вентилятору або лабораторного компресору подається у реакторну камеру озонатора. Електричні складові озонатора, що став основою для дослідного стенду, були зібрані з використанням принципів електричної теорії Філіпова [7] і значно не відрізняються від класичних зразків, що описані для такого обладнання але з урахуванням вище зазначених відмінностей, а також деяких конструктивних особливостей, що зумовлені потребами проведення досліджень.

На рис. 6 наведено зображення дослідного стенду Лоз-1. Як видно з рисунку (рис. 6, А) лабораторна установка має панель керування, на якій знаходиться: 1 - вимикач; 2 - світловий індикатор інтенсивності розряду; 3, 4 - точне та грубе регулювання інтенсивності розряду; 5 - запобіжник; 6 - вихідний патрубок. На рис. 6, Д та Е під номером 7 позначений вентилятор, що нагнітає повітря, тобто він крізь вхідну решітку (рис. 6, Б) всмоктує повітря, та направляє його у реакторну камеру 8 (рис. 6, Д та Е), а також для охолодження елементів схеми приладу. Реактор озонатору рис. 7 складається з: 1 - рамки кріплення електродів; 2 - аноду і 3 - катоду, що зроблені із мідних пластин; 4 - діелектричної скляної пластини; 5 - кріплення-зажиму. В конструкцію озонатору приладу Лоз-1 закладена можливість регулювання розрядного проміжку і зміни діелектричної складової у реакторі. Також слід зазначити, що вихідний патрубок 6 (рис. 6) обладнаний додатковим отвором для підключення повітряного компресора, який дозволяє збільшити потужність вихідного 


\section{$\underline{5}$ ТЕОРІЯ I ПРАКТИКА АВТОМАТИЗАЦІЇ БІЗНЕС-ПРОЦЕСІВ}

потоку (тобто, швидкість і об’ємну вихідного газового потоку), а сама кінцева частина патрубка обладнана решіткою-запобіжником.

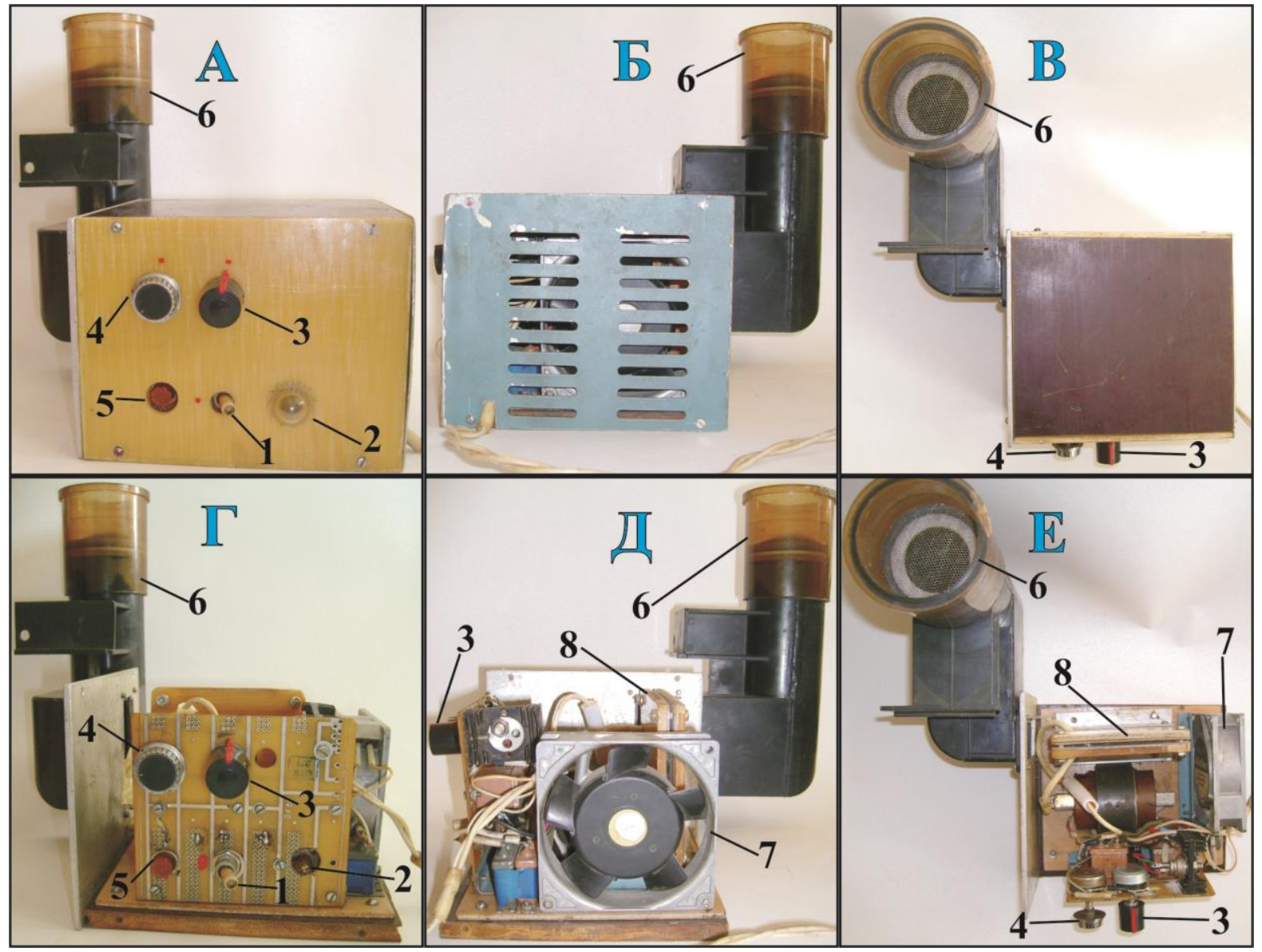

Рис. 6. Лабораторний озонатор Лоз-1. А - вид з переду; Б - вид на задню панель із вхідною решіткою; В - вид з верху; Г, Д, Е - теж саме що і А, Б, В, але без зовнішньої кришки.

Таке конструктивне рішення дозволяє проводити дослідження із сировиною, яка має різні фізико-технічні показники, наприклад стає можливим засипати дослідний матеріал (приміром, зерно пшениці) у вихідний отвір

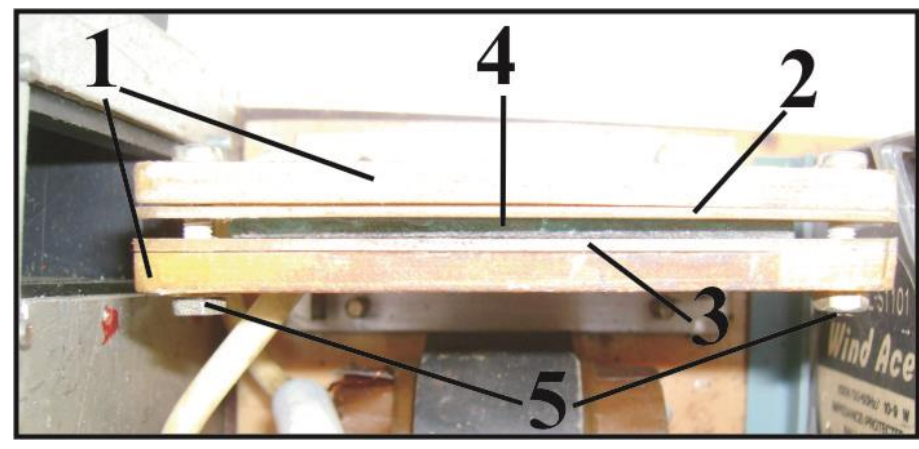

Рис. 7. Реактор озонатору Лоз-1 патрубку та пропускати крізь нього синтезовану у реакторі озоно-повітряну суміш (ОПС), знизу вгору, імітуючи таким чином обробку БРП, що знаходяться у насипу. При необхідності збільшення потужності повітряного потоку, який нагнітає вентилятор приладу, можливо збільшити тиск повітря за рахунок підключення до патрубку додаткового повітряного компресора. При цьому конструктивно передбачена можливість підключення до патрубку додаткових вимірювальних трубочок, як до, так і після камери з дослідним матеріалом. Це, в свою чергу, дозволяє вимірювати концентрацію озону у ОПС, до та після їі проходження крізь дослідний матеріал, та контролювати основні параметри процесу. Регулювання концентрації озону у вихідній суміші виконується за допомогою регуляторів інтенсивності розряду, а також, при необхідності, за рахунок підключення до вихідного патрубка додаткового 


\section{$\underline{5}$ ТЕОРІЯ I ПРАКТИКА АВТОМАТИЗАЦІЇ БІЗНЕС-ПРОЦЕСІВ}

компресора, який нагнітає додатковий потік повітря, що розбавляє основний потік ОПС до необхідної концентрації.

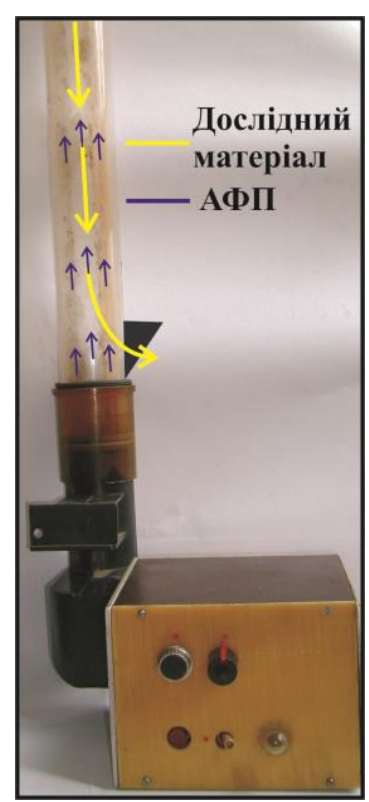

Рис. 8. Потокова схема стенду на базі Лоз-1
Попереднє налаштування реактора пристрою складається з вибору діелектричного матеріала (рис. 7,4 ), його товщини, та розміру розрядного проміжку, який, в свою чергу, можливо регулювати з допомогою кріплення-зажима (рис. 7, 5).

Ще однією особливістю даної конструкції прилада $\epsilon$ можливість з’єднання вихідного патрубку з додатковим компонентом (прозорою трубою зі спеціальними отворами), який при необхідності допоможе імітувати обробку сипучого матеріалу у потоці згідно схемі, зображеній на рис. 8. Завдяки чому, ми отримуємо лабораторну установку, яка спроможна виробляти ОПС з заданою регульованою концентрацією озону на виході, можливістю зміни бар'єрних елементів реактора, та пристосовану для обробки активною формою повітря (АФП) дослідного матеріала у насипу та в потоці при гравітаційному транспортуванні сипких БРП (наприклад зерна пшениці) самопливом.

На рис. 9 приведена електрична принципова схема озонатора дослідного стенда Лоз-1. Вагомою відмінністю цієї схеми від існуючих прототипів $є$ використання генератора імпульсів, у цій якості виступає тиристор VS, керування яким здійснюється по аноду. Використання цього елемента дозволяє регулювати подачу струму на трансформатор ТА, за рахунок зміни частоти імпульсів, яка, в свою чергу, регулюється за допомогою опорів, що керуються R3 та R4. Світловий індикатор HL дозволяе візуалізувати режим роботи тиристору VS, крізь який проходить струм, тобто частоту та інтенсивність розрядів, що виникають у реакторі озонатора. Таким чином, за допомогою імпульсного керування, можливо виконувати регулювання концентрації озону, що синтезується у реакторі. Також слід зазначити що, в залежності від використаного у реакторі діелектричного шару, властивостей матеріалу 3 якого він зроблений, необхідно підбирати характеристики трансформатора струму, що підвищує, таким чином, щоб потужності виникаючого на електродах заряду було достатньо для “пробою” діелектричного бар'єра. Саме тому в конструкції приладу був використаний трансформатор авторської розробки, складові частини якого зроблені таким чином, щоб при необхідності його можливо було «перемонтувати», тобто змінити кількість витків у внутрішній та зовнішній обмотках $\mathrm{i}$ забезпечити, відповідну до параметрів діелектричного бар’єру і потреб досліду, потужність розряду.

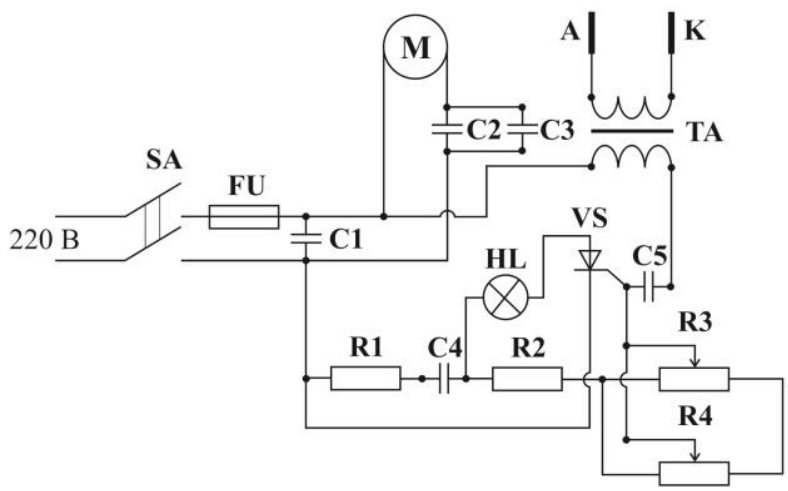

\begin{tabular}{|c|c|}
\hline \begin{tabular}{|c|} 
Умовні \\
позначення
\end{tabular} & Найменування \\
\hline SA & Тумблер двухпозиційний \\
\hline FU & Запобіжник $5 \mathrm{~A}$ \\
\hline C1 & Конденсатор МБГО 500В, 1 мкф, $\pm 10 \%$ \\
\hline $\mathrm{C2}$ & Конденсатор МБГО 600В, 0,25 мкф, $\pm 10 \%$ \\
\hline C3 & Конденсатор МБГО $300 \mathrm{~B}, 1$ мкф, $\pm 10 \%$ \\
\hline $\mathrm{C} 4$ & Конденсатор МБГО 250В, 0,1 мкф, $\pm 10 \%$ \\
\hline C5 & Конденсатор МБГО 600В, 0,25 мкф, $\pm 10 \%$ \\
\hline R1 & Опір МЛТ-2 220, 5\% \\
\hline $\mathbf{R 2}$ & Опір МЛТ-1 1,0, К10\% \\
\hline $\mathbf{R 3}$ & Опір що регулюється А-2 Вт, 330К \\
\hline R4 & $\begin{array}{l}\text { Опір що регулюється СП-У, 8В3Ро7, 0,25 Вт, } \\
220 К\end{array}$ \\
\hline HL & Неоновый светодиод \\
\hline VS & Тиристор КУ208Г, 8802 \\
\hline $\mathbf{M}$ & $\begin{array}{l}\text { Мотор вентилятора Wind Ace, V92-BJL-S1101, } \\
110 \mathrm{~V} / 50-60 \mathrm{~Hz} / 10-9 \mathrm{~W}\end{array}$ \\
\hline TA & Трансформатор струмовий, що підвищуе \\
\hline $\mathbf{A}, \mathbf{K}$ & Анод и катод реактора \\
\hline
\end{tabular}

Примітка:

Трансформатор авторської розробки за результатами досліджень, характеристики якого можуть бути змінені в залежності від використаного діелектричного матеріалу у реакторі приладу

Рис. 9. Принципова електрична схема озонатора дослідного стенда Лоз-1 


\section{$\underline{5}$ ТЕОРІЯ І ПРАКТИКА АВТОМАТИЗАЦІЇ БІЗНЕС-ПРОЦЕСІВ}

Максимальна виробнича потужність озонатора, що вмонтовано у стенд Лоз-1 складає 3,6 г $\left(\mathrm{O}_{3}\right) /$ год. за умови, що для нагнітання повітря у реактор використовується тільки вентилятор приладу, який у свою чергу

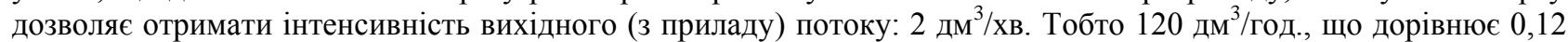
$\mathrm{M}^{3} /$ год.

\section{Висновки}

На підставі вхідних технічних характеристик, що були сформовані у відповідності до технологічних ділянок на яких проводиться обробка БРП повітрям у потоці та насипу, із використанням типових конструкцій і рішень, спираючись на літературні джерела, був розроблений і змонтований дослідний стенд Лоз-1. Завдяки основним рішенням закладеним у конструкцію дослідного стенду, стало можливим проводити дослідження режимів управління технологічним процесом обробки БРП повітрям, збагаченим озоном, і впливу ПЗО на властивості БРП при їх обробці у насипу і в потоці.

\section{Література}

1. Бабков, А.В. Розробка експериментального обладнання для дослідження управління процесом синтезу озона [Текст] / А.В. Бабков // Автоматизація технологічних і бізнес процесів / Щоквартальний наукововиробничій журнал - № 17, Одеса: ОНАХТ, 2014 р., С. 37-45;

2. O’Donnell, Colm Ozone in food processing [Текст] / Colm O’Donnell, B.K. Tiwari, P.J. Cullen, Rip G. Rice - WILEY-BLACKWELL, 2012, - 300 p;

3. Лунин, В.В. Физическая химия озона [Текст] / В.В. Лунин, М.П. Попович, С.Н. Ткаченко — М: Изд во МГУ, 1998 г., — 480 с;

4. Силкин, Е. Синтез озона в электрических разрядах и повышение его эффективности. Часть 1 [Текст] // Е. Силкин / КОМПОНЕНТЫ И ТЕХНОЛОГИИ - 2008 г. - № 6, - С. 136-143, [Електронний ресурс]. Режим доступа: http://www.kit-e.ru/assets/files/pdf/2008_6_136.pdf;

5. Шаброва, Е.Б. Влияние свойств и состава стеклокерамических и стеклоэмалевых покрытий электродов на электросинтез озона в барьерном разряде [Текст] // Е.Б. Шаброва /Диссертация на соискание ученой степени кандидата химических наук - М: МГУ им. М.В. Ломоносова, 2000 г., - 121 с;

6. Таланов, Н. Домашний озонатор [Текст] // Н. Таланов, В. Фомин / РАДИО - 1993 г, №8, Нижний Новгород, С. 47-56;

7. Филиппов, Ю.В. Электросинтез озона. / Ю.В. Филиппов, В.А. Вобликова, В.И. Пантелеев - М.: Изд во МГУ, 1987 г., - 236 с.

\section{Ц ЦИТАТА НОМЕРА}

\section{,Для того, чтобы какая-нибудь наука \\ сдвинулась с места, чтобы расиирение ее}

стало совериеннее, гипотезы необходимы так жсе,

как показания опыта и наблюдения"

(Гёте И.) 